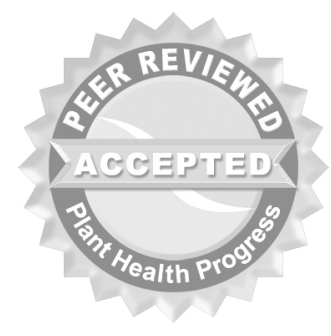

(C) 2009 Plant Management Network.

Accepted for publication 12 January 2009. Published 12 March 2009.

\title{
Cotton Cultivars Evaluated for Tolerance to Reniform Nematode
}

\author{
Salliana R. Stetina, USDA-ARS Crop Genetics and Production \\ Research Unit, P.O. Box 345, Stoneville, MS 38776; \\ Gabriel L. Sciumbato, Mississippi State University Delta Research \\ and Extension Center, P.O. Box 197, Stoneville, MS 38776; \\ Law rence D. Young, USDA-ARS Crop Genetics and Production \\ Research Unit, P.O. Box 345, Stoneville, MS 38776; and \\ J ulie A. Blessitt, Mississippi State University Delta Research and \\ Extension Center, P.O. Box 197, Stoneville, MS 38776 \\ Corresponding author: Salliana R. Stetina. Sally.Stetina@ars.usda.gov
}

Stetina, S. R., Sciumbato, G. L., Young, L. D., and Blessitt, J. A. 2009. Cotton cultivars evaluated for tolerance to reniform nematode. Online. Plant Health Progress doi:10.1094/PHP-2009-0312-01-RS.

\begin{abstract}
Thirty-nine commercial cotton (Gossypium hirsutum) cultivars were evaluated to identify those with tolerance to reniform nematode (Rotylenchulus reniformis). Trials were conducted for three years at two west-central Mississippi field locations naturally infested with reniform nematode. Main plots were cultivars and subplots were either not treated or treated with nematicide. Reniform nematode soil population densities were assessed throughout the growing season. At harvest, seed cotton yields were determined, and fiber quality was evaluated for select samples. Data were pooled from all years and locations, and t-tests were used to identify tolerant cultivars. Cultivars were judged tolerant if nematicide did not improve yield, although the nematode population was reduced at a midseason sampling interval. Only Deltapine 449 BR, Paymaster 1218 BR, and Suregrow 215 BR met these criteria. Additionally, tolerance indices were calculated for nine cultivars showing suppressed nematode populations in nematicide-treated plots at any point during the growing season. The three tolerant cultivars identified based on the t-tests ranked first (Suregrow 215 BR), second (Paymaster $1218 \mathrm{BR}$ ), and fifth (Deltapine 449 BR) with respect to tolerance index. Because they do not appear to suffer significant yield loss due to reniform nematode, these three cultivars may benefit growers.
\end{abstract}

\section{I ntroduction}

The reniform nematode (Rotylenchulus reniformis) has become the predominant phytoparasitic nematode on cotton (Gossypium hirsutum) in the Mid South area of the United States. Average losses to this pathogen from 2003 through 2005, when this study was conducted, were estimated to be $4.5 \%, 8.3 \%$, and $8.5 \%$ in Louisiana, Mississippi, and Alabama, respectively $(4,5,6)$. Just over 1 million bales of cotton were estimated to be lost due to reniform nematode damage in these three states during this period $(4,5,6)$. The situation has not improved over time, as the most recent report cites losses of $4.0 \%$ in Louisiana, 9.0\% in Mississippi, and 8.5\% in Alabama (3). Damage by the reniform nematode has been implicated as a factor in cotton yield stagnation over the past two decades (2). Infected cotton plants produce fewer and smaller bolls and also exhibit reductions in lint percentage $(9,15,19)$.

Because reniform nematode is established in the Mid South, methods to reduce damage are needed. The primary management practice to minimize reniform nematode damage to cotton is the use of nematicides (18), though they are costly and are associated with health hazards and environmental risks.

Rotation to nonhost crops such as corn, peanut, or nematode resistant soybean has been demonstrated to help reduce losses to reniform nematode $(11,13,25,27)$, but the practice has not been widely accepted by Mid South 
growers primarily because rotational crops such as corn historically have been less profitable than cotton. Studies evaluating rotation to corn or resistant soybean in Georgia and North Carolina (11) and to corn in Mississippi (25) demonstrated that while reniform nematode populations were suppressed by the nonhost rotation crop as compared to cotton monoculture, they rebounded to levels seen on cotton by the end of the first season back in cotton. Unfortunately, no cotton cultivars are commercially available that have resistance to reniform nematode $(18,19,22)$, and it will likely be years in the future before host resistance is widely available.

Tolerant cultivars will not exhibit significant yield loss even while allowing the nematode to infect and reproduce unchecked (1). Tolerance differs from resistance in that resistant cultivars avoid injury or loss by suppressing the pathogen population by allowing little or no infection and reproduction. Relatively few studies have been conducted to identify tolerance to economically important nematodes in cotton. Koenning and Bowman (17) reported significant levels of tolerance to Columbia lance nematode (Hoplolaimus columbus) in early- and late-season commercial cultivars adapted to North Carolina. Davis and May (12) evaluated 19 advanced breeding lines for tolerance to root-knot nematode (Meloidogyne incognita race 3) and reported that six and nine of the cotton lines evaluated in the first and second years of the study, respectively, were tolerant; only three lines were classified as tolerant in both years of the study. In studies conducted in Texas, Cook et al. (10) assessed tolerance to reniform nematode in six experimental cotton breeding lines. They reported that the breeding lines had good yield potential in fields infested with reniform nematode, and greenhouse trials confirmed that reniform nematode populations were not suppressed on any of the lines. Work by Koenning et al. (16) compared several breeding lines previously identified as tolerant by Cook et al. (10) with commercial cultivars in North Carolina trials. While the putatively tolerant lines had higher tolerance indices than the commercial cultivars, their overall yields were below the level considered acceptable in North Carolina. A recent study by Usery et al. (26) evaluated approximately 40 commercial cultivars in field trials in northern and southern Alabama and found that none were consistently tolerant to the reniform nematode. Together, these reports indicate that expression of tolerance may vary from one geographic location to another.

Tolerance is not an ideal pest management solution because it allows the pest population to exist at or above levels that can damage susceptible cultivars. But, until cotton cultivars with resistance to reniform nematode become available, the use of a tolerant cultivar could help growers minimize losses to this pest. The primary objective of this project was to evaluate commercial cotton cultivars for tolerance to the reniform nematode in west-central Mississippi. Additionally, qualitative fiber properties were assessed to evaluate whether or not they varied due to nematode pressure. Preliminary reports have been published $(23,24)$.

\section{Field Evaluation for Tolerance to Reniform Nematode}

To identify tolerance in commercially available cotton, a total of 39 cultivars were evaluated in three field trials at two west-central Mississippi locations, Stoneville and Elizabeth (Table 1). Trial 1 was conducted at Stoneville in 2003 and 2004 in a Dundee fine sandy loam soil (fine-silty, mixed, active, thermic Typic Endoaqualfs). Trial 2 was conducted at Elizabeth in 2003 and 2004 in a Bosket very fine sandy loam soil (fine-silty, mixed, active, thermic Aquic Hapludalfs). Trial 3 was conducted at both the Stoneville and Elizabeth sites in 2005. All trials were conducted in fields that were naturally infested with reniform nematode at population levels exceeding the action threshold of 423 nematodes per $200 \mathrm{~cm}^{3}$ (1,000 per pint) of soil at planting for Mississippi (20). Treatments in each trial were arranged in a split-plot design. The main plot treatment was cultivar, arranged in a randomized complete block with either 6 (Stoneville 2003 and 2004) or 4 (Stoneville 2005 and all Elizabeth trials) replications. Subplots were either not treated or treated with nematicide (aldicarb or 1,3-dichloropropene) at recommended rates. In Trial 1, aldicarb (Temik 15 G; Bayer Crop Science, Research Triangle Park, NC) was first applied 
at a rate of $5.60 \mathrm{~kg} / \mathrm{ha}$ in furrow at planting on 15 May 2003 (Stoneville) and 29 April 2004 (Stoneville), then sidedressed at a rate of $7.84 \mathrm{~kg} / \mathrm{ha}$ when the plants reached the pinhead square stage of development. In Trials 2 and 3, fumigation with 1,3-dichloropropene (Telone II; Dow AgroSciences, Indianapolis, IN) at a rate of 28.05 liter/ha on 28 March 2003 (Elizabeth), 6 April 2004 (Elizabeth), and 5 April 2005 (Stoneville and Elizabeth) occurred approximately three weeks prior to planting. The fumigant was applied at a depth of 35 to $40 \mathrm{~cm}$ using a modified fertilizer applicator. Trials in which 1,3-dichloropropene was used were planted on 22 April 2003 (Elizabeth), 21 April 2004 (Elizabeth), and 20 April 2005 (Stoneville and Elizabeth). Subplots consisted of 4 rows spaced $1 \mathrm{~m}$ apart by $12.2 \mathrm{~m}$ long. Fertilizer and pesticides were applied according to standard recommendations for Mississippi, except that the use of insecticides with nematicidal properties was avoided. Plants were furrow irrigated as needed during each growing season.

Table 1. Cotton cultivars evaluated in reniform nematode tolerance trials conducted in west-central Mississippi from 2003 through 2005.

\begin{tabular}{|c|c|c|c|}
\hline Trial & 1 & 2 & 3 \\
\hline Cultivars & \begin{tabular}{|l} 
BCG 28 BR* \\
Deltapine 436 R \\
Deltapine 444 BR \\
Deltapine 449 BR \\
Deltapine 5415 R \\
Deltapine 555 BR \\
Deltapine 5690 R \\
Deltapine 655 BR \\
Fibermax 800 BR \\
Fibermax 960 BR \\
Fibermax 989 BR \\
Fibermax 991 BR \\
Paymaster 1199 R \\
Paymaster $1218 \mathrm{BR}$ \\
Stoneville 4892 BR \\
Stoneville 5599 R \\
Suregrow 215 BR \\
Suregrow 521 R
\end{tabular} & $\begin{array}{l}\text { Deltapine } 20 \text { B } \\
\text { Deltapine } 428 \text { B } \\
\text { Deltapine } 555 \text { BR } \\
\text { Fibermax } 958 \\
\text { Fibermax } 966 \\
\text { Miscot MS } 8806 \\
\text { Paymaster } 1218 \text { BR } \\
\text { Paymaster } 1560 \text { B } \\
\text { Phytogen PSC } 355 \\
\text { Stoneville BXN 47 } \\
\text { Stoneville BXN 49 B } \\
\text { Stoneville 4691 B } \\
\text { Stoneville 474 } \\
\text { Stoneville 4892 BR } \\
\text { Suregrow } 125 \text { BR } \\
\text { Suregrow 501 BR } \\
\text { Suregrow } 747\end{array}$ & \begin{tabular}{|l} 
BCG 28 BR \\
Deltapine 424 BR \\
Deltapine 434 R \\
Deltapine 436 R \\
Deltapine 444 BR \\
Deltapine 449 BR \\
Deltapine 5415 R \\
Deltapine 555 BR \\
Deltapine 5690 R \\
Fibermax 800 BR \\
Fibermax 960 BR \\
Fibermax 966 \\
Fibermax 991 BR \\
Paymaster $1218 \mathrm{BR}$ \\
Paymaster $1560 \mathrm{~B}$ \\
Phytogen PSC 410 R \\
Stoneville 4892 BR \\
Stoneville 5599 R \\
Suregrow 105 \\
Suregrow $125 \mathrm{BR}$ \\
Suregrow 215 BR \\
Suregrow 501 BR
\end{tabular} \\
\hline
\end{tabular}

* $\mathrm{B}=$ Bollgard, $\mathrm{R}=$ Roundup Ready.

Reniform nematode populations were quantified from soil samples collected from each subplot at planting, midseason, and harvest. Six cores (30 cm deep and $2.5 \mathrm{~cm}$ in diameter) taken from the center two rows of each plot using a soil probe were combined and a $200-\mathrm{cm}^{3}$ subsample was processed. Reniform nematodes extracted by elutriation (7) and sucrose centrifugation (14) were counted at 50× magnification using an inverted microscope.

Seed cotton was mechanically harvested from the center two rows of each plot using either a Case International Harvester two-row picker (Case International Harvester, Racine, WI) (Elizabeth plots) or a John Deere two-row picker (John Deere \& Company, Moline, IL) (Stoneville plots). Yields at Elizabeth were determined using an automated weigh system installed in the picker (Avery Weigh-Tronix model WI-130, Fairmont, MN). Seed cotton from the Stoneville plots was bagged and weighed. The only exceptions occurred at Elizabeth in 2003 and 2004, when a 50-boll sample for fiber quality assessment was collected by hand from one of the center rows in each plot prior to mechanical harvest. The weight of this sample was added to the mechanicallydetermined weight to determine plot yield for these two environments. Plots were harvested on 11 September 2003, 21 September 2004, and 21 September 2005 at Elizabeth and on 14 November 2003, 24 September 2004, and 3 October 2005 at Stoneville. 
Because preliminary analysis showed no significant environmental effects, data from all years and locations were pooled and tolerant cultivars were identified from paired plots using one-tailed t-tests (SAS PROC MIXED, SAS Institute Inc., Cary, NC). Reniform nematode counts were transformed $\left(\log _{10} \mathrm{x}+1\right)$ prior to analysis to normalize the data. Cultivars for which nematicide significantly $(\mathrm{P} \leq 0.05)$ reduced the nematode population at a midseason sampling interval but for which there was no corresponding improvement in cotton yield were judged to be tolerant. In addition, tolerance indices (17) were calculated and compared using differences of least squares means $(\mathrm{P} \leq 0.05)$ for cultivars that showed suppressed nematode populations in nematicide-treated plots at any point during the growing season:

$$
\text { index }=\left(\text { yield }_{\text {nontreated }} / \text { yield }_{\text {treated with nematicide }}\right){ }^{*} 100 .
$$

Of the 39 cultivars evaluated, only Deltapine 449 BR, Paymaster 1218 BR, and Suregrow 215 BR were identified as being tolerant to reniform nematode. For these three cultivars, significant suppression of the nematode population at midseason did not result in higher yields at harvest (Table 2). The remaining cultivars did not meet these criteria. In many instances, the nematicide did not suppress the reniform nematode population at midseason enough for differences in populations in treated and nontreated plots to be significant (Table 2). Unfortunately, increasing the amount of nematicide applied to further reduce the reniform nematode population was not an option based on label restrictions. Therefore, tolerance level could not be reliably measured for these cultivars and further investigation is needed to determine their tolerance levels.

Table 2. Midseason reniform nematode populations and seed cotton yields for cotton varieties evaluated from 2003 through 2005 in west-central Mississippi.

\begin{tabular}{|c|c|c|c|c|}
\hline \multirow[b]{2}{*}{ Cultivar } & \multicolumn{2}{|c|}{$\begin{array}{l}\text { Reniform nematodes } \\
\text { (number / } 200 \mathrm{~cm}^{3} \text { soil) }\end{array}$} & \multicolumn{2}{|c|}{$\begin{array}{c}\text { Seed cotton yield } \\
\text { (g/plot) }\end{array}$} \\
\hline & Nematicide & Not treated & Nematicide & Not treated \\
\hline BCG $28 \mathrm{BR}^{\mathrm{Y}}$ & 1897 a & 2309 a & 6338 a & $6204 a$ \\
\hline Deltapine $20 \mathrm{~B}^{\mathrm{X}}$ & $1624 \mathrm{~b}$ & 3397 a & 7811 a & $6646 \mathrm{~b}$ \\
\hline Deltapine $424 \mathrm{BR}^{\mathrm{X}}$ & 3039 a & $2073 \mathrm{a}$ & 8716 a & 6602 b \\
\hline Deltapine $428 B^{\mathrm{X}}$ & $2351 \mathrm{a}$ & $3202 \mathrm{a}$ & $7261 \mathrm{a}$ & $6498 a$ \\
\hline Deltapine $434 \mathrm{R}^{\mathrm{X}}$ & 2609 a & $2595 \mathrm{a}$ & $7296 a$ & $6624 \mathrm{a}$ \\
\hline Deltapine $436 \mathrm{R}^{\mathrm{y}}$ & 2397 a & 3723 a & 7924 a & 7569 a \\
\hline Deltapine $444 \mathrm{BR}^{\mathrm{Y}}$ & $2295 \mathrm{a}$ & 3627 a & 8495 a & $7575 b$ \\
\hline Deltapine $449 \mathrm{BR}^{\mathrm{Y}}$ & $863 b$ & $1612 \mathrm{a}$ & 7148 a & $6717 a$ \\
\hline Deltapine $5415 \mathrm{R}^{\mathrm{y}}$ & $2900 \mathrm{a}$ & $3672 \mathrm{a}$ & $6876 \mathrm{a}$ & $6734 a$ \\
\hline Deltapine $555 \mathrm{BR}^{\mathrm{Y}}$ & $2497 a$ & $3083 a$ & $6330 \mathrm{a}$ & $6034 a$ \\
\hline Deltapine $5690 \mathrm{R}^{\mathrm{Y}}$ & $2143 a$ & $1774 \mathrm{a}$ & 5962 a & $5656 a$ \\
\hline Deltapine 655 BR $^{\mathrm{X}}$ & 2332 a & 3725 a & $6615 a$ & $5836 \mathrm{~b}$ \\
\hline Fibermax $800 \mathrm{BR}^{\mathrm{Y}}$ & $3550 \mathrm{a}$ & $3091 \mathrm{a}$ & 5790 a & $5514 \mathrm{a}$ \\
\hline Fibermax $958^{x}$ & $1926 \mathrm{a}$ & $2367 a$ & $6933 a$ & $6346 a$ \\
\hline Fibermax $960 \mathrm{BR}^{\mathrm{y}}$ & 2903 a & $3472 \mathrm{a}$ & $7351 \mathrm{a}$ & $6752 b$ \\
\hline Fibermax $966^{\mathrm{Y}}$ & $2330 \mathrm{a}$ & $1834 \mathrm{a}$ & $6975 \mathrm{a}$ & $6563 a$ \\
\hline Fibermax 989 BR $^{\mathrm{X}}$ & $2818 a$ & $1054 \mathrm{a}$ & $6616 a$ & $6589 a$ \\
\hline Fibermax $991 \mathrm{BR}^{\mathrm{Y}}$ & $2643 a$ & $2392 \mathrm{a}$ & $6230 \mathrm{a}$ & $5316 b$ \\
\hline Miscot MS $8806^{x}$ & $2367 a$ & $2254 \mathrm{a}$ & $7295 \mathrm{a}$ & $6312 b$ \\
\hline
\end{tabular}

(continued) 
Table 2. (continued)

\begin{tabular}{|c|c|c|c|c|}
\hline \multirow[b]{2}{*}{ Cultivar } & \multicolumn{2}{|c|}{$\begin{array}{l}\text { Reniform nematodes } \\
\text { (number / } 200 \mathrm{~cm}^{3} \text { soil) }\end{array}$} & \multicolumn{2}{|c|}{$\begin{array}{c}\text { Seed cotton yield } \\
(\mathrm{g} / \mathrm{plot})\end{array}$} \\
\hline & Nematicide & Not treated & Nematicide & Not treated \\
\hline Paymaster $1199 \mathrm{R}^{\mathrm{X}}$ & 1877 a & $2324 \mathrm{a}$ & $7431 \mathrm{a}$ & $6800 \mathrm{a}$ \\
\hline Paymaster $1218 \mathrm{BR}^{\mathrm{Z}}$ & $493 \mathrm{~b}$ & 922 a & $7691 \mathrm{a}$ & $7426 a$ \\
\hline Paymaster $1560 \mathrm{~B}^{\mathrm{Y}}$ & 2909 a & 3068 a & $7083 a$ & $6713 a$ \\
\hline Phytogen PSC $355^{\mathrm{x}}$ & 2903 a & 2983 a & $7255 \mathrm{a}$ & $6762 \mathrm{a}$ \\
\hline Phytogen PSC $410 \mathrm{R}^{\mathrm{X}}$ & $2700 \mathrm{a}$ & $2492 \mathrm{a}$ & $7163 \mathrm{a}$ & $8485 \mathrm{a}$ \\
\hline Stoneville BXN $47^{\mathrm{X}}$ & $2102 \mathrm{a}$ & $3095 \mathrm{a}$ & $6965 \mathrm{a}$ & $6549 a$ \\
\hline Stoneville BXN $49 B^{X}$ & 2327 a & $2688 \mathrm{a}$ & $7094 \mathrm{a}$ & $6667 \mathrm{a}$ \\
\hline Stoneville $4691 \mathrm{~B}^{\mathrm{X}}$ & 2838 a & $3171 \mathrm{a}$ & $7311 \mathrm{a}$ & $6938 \mathrm{a}$ \\
\hline Stoneville $474^{\mathrm{x}}$ & $2402 \mathrm{a}$ & $2237 a$ & $7009 a$ & $6683 a$ \\
\hline Stoneville 4892 BR $^{\mathrm{Z}}$ & $798 \mathrm{~b}$ & $1460 \mathrm{a}$ & $7151 \mathrm{a}$ & $6517 b$ \\
\hline Stoneville $5599 \mathrm{R}^{\mathrm{Y}}$ & 1999 a & $1946 \mathrm{a}$ & $6638 a$ & $7465 a$ \\
\hline Suregrow $105^{\mathrm{y}}$ & $1868 \mathrm{a}$ & 2467 a & $7087 \mathrm{a}$ & $6788 \mathrm{a}$ \\
\hline Suregrow $125 \mathrm{BR}^{\mathrm{Y}}$ & 2146 a & $2780 \mathrm{a}$ & 7206 a & $6831 \mathrm{a}$ \\
\hline Suregrow $215 \mathrm{BR}^{\mathrm{Y}}$ & $779 \mathrm{~b}$ & $1561 \mathrm{a}$ & $7204 a$ & $7445 a$ \\
\hline Suregrow 501 BR $^{\mathrm{Y}}$ & $2622 a$ & $2548 a$ & $7126 a$ & $6565 a$ \\
\hline Suregrow $521 \mathrm{R}^{\mathrm{X}}$ & $3484 \mathrm{a}$ & $2375 \mathrm{a}$ & $6541 \mathrm{a}$ & $6892 \mathrm{a}$ \\
\hline Suregrow $747^{x}$ & $2614 \mathrm{a}$ & $2747 a$ & $7467 \mathrm{a}$ & $7121 \mathrm{a}$ \\
\hline
\end{tabular}

Within each cultivar and parameter, means followed by the same letter are not significantly different (one-tailed t-test, $\mathrm{P} \leq 0.05$ ).

$x$ Data are averaged across 2 environments (location $\times$ year combinations).

$y$ Data are averaged across 4 environments (location $\times$ year combinations).

$\mathrm{z}$ Data are averaged across 6 environments (location $\times$ year combinations).

Nine cultivars showed suppressed reniform nematode populations on at least one sampling date during the growing season: Deltapine $20 \mathrm{~B}$ (midseason), Deltapine $436 \mathrm{R}$ (planting), Deltapine 449 BR (midseason and harvest), Deltapine 655 BR (harvest), Fibermax 800 BR (planting), Fibermax 960 BR (planting and harvest), Paymaster 1218 BR (midseason), Suregrow 215 BR (midseason), and Stoneville 4892 BR (midseason). Tolerance indices for these cultivars are provided in Table 3 . Differences of least squares means showed that Suregrow 215 BR's tolerance index of 106.4 was significantly higher than Deltapine 20 B's tolerance index of 85.8, though neither of these cultivars differed from the others evaluated. The three cultivars identified as being tolerant based on the t-tests ranked first (Suregrow 215 BR), second (Paymaster 1218 BR), and fifth (Deltapine 449 BR) with respect to tolerance index.

Eight of the cultivars evaluated apparently benefitted from nematicide application, as indicated by significantly higher yields in treated plots. Deltapine 20 B and Stoneville 4892 BR showed increased yields associated with significantly reduced reniform nematode populations (Table 2), suggesting that the nematicidal effects of the pesticide were important for achieving maximum yield in these cultivars. Deltapine 424 BR, Deltapine 444 BR, Deltapine 655 BR, Fibermax 96o BR, Fibermax 991 BR, and Miscot MS 8806 showed a yield increase in plots treated with nematicide, though significant suppression of the reniform nematode population was not achieved (Table 2). This suggests that effects of the pesticide on nontarget organisms, such as suppression of early season thrips, also may be contributing to improved cotton yields for these cultivars. Additional studies would be needed to confirm this hypothesis, as data on pressure from insects and other pests were not collected in the current study. 
Table 3. Tolerance indices for cotton cultivars associated with suppressed reniform nematode populations in nematicide-treated plots from 2003 through 2005 in west-central Mississippi.

\begin{tabular}{|l|c|}
\hline Cultivar & Tolerance index \\
\hline Suregrow $215 \mathrm{BR}^{\mathrm{Y}}$ & $106.4 \mathrm{a}$ \\
\hline Paymaster $1218 \mathrm{BR}^{\mathrm{Z}}$ & $98.7 \mathrm{ab}$ \\
\hline Fibermax $800 \mathrm{BR}^{\mathrm{y}}$ & $97.1 \mathrm{ab}$ \\
\hline Deltapine 436 $\mathrm{R}^{\mathrm{y}}$ & $96.6 \mathrm{ab}$ \\
\hline Deltapine 449 $\mathrm{BR}^{\mathrm{y}}$ & $95.9 \mathrm{ab}$ \\
\hline Stoneville 4892 BR & $95.4 \mathrm{ab}$ \\
\hline Fibermax $960 \mathrm{BR}^{\mathrm{Y}}$ & $93.0 \mathrm{ab}$ \\
\hline Deltapine $655 \mathrm{BR}^{\mathrm{X}}$ & $90.2 \mathrm{ab}$ \\
\hline Deltapine $20 \mathrm{~B}^{\mathrm{X}}$ & $85.8 \mathrm{~b}$ \\
\hline
\end{tabular}

Means followed by the same letter are not significantly different

(differences of least squares means, $\mathrm{P} \leq 0.05$ ).

$x$ Data are averaged across 2 environments (location $\times$ year combinations).

$y$ Data are averaged across 4 environments (location $\times$ year combinations).

$\mathrm{z}$ Data are averaged across 6 environments (location $\times$ year combinations).

\section{I nfluence of Nematodes and Nematicide Application on Cotton Fiber Quality}

Both yield and fiber quality are important to cotton growers. A cultivar might produce a sufficient quantity of fiber, but if the fiber is of inferior quality it will not receive the highest possible price at market. Fiber quality can be impacted by a number of genetic and environmental factors. Yield reductions due to plant stress caused as reniform nematodes feed on roots has been consistently documented $(15,18,22)$, while the effect on fiber quality has been reported from fewer studies. A 1959 study by Jones et al. (15) concluded that length, strength, and fineness of fiber were not affected by reniform nematode. In the early 1990 , Cook and Namken $(8,9)$ reported that micronaire, length, strength, elongation, and uniformity in selected cotton breeding lines, germplasm releases, and cultivars were not affected by reniform nematode. However, there have been no reports of the impact of reniform nematode on fiber quality in modern cultivars.

To examine the relationship between fiber quality and reaction to reniform nematode in modern cultivars, samples were collected from the 18 cultivars grown at the Elizabeth location during 2003 and 2004 to assess fiber quality. At harvest, 50-boll samples were collected by hand from one of the center rows in each subplot. The samples were ginned and a $15 \mathrm{~g}$ subsample of lint was sent to a commercial lab (Starlab Incorporated, Knoxville, TN) for fiber quality determination. Data on micronaire, elongation, strength, and length $(50 \%$ and $2.5 \%$ span length) (21) were subjected to analysis of variance (SAS PROC MIXED, SAS Institute Inc., Cary, NC) to identify parameters with significant nematicide or cultivar $\times$ nematicide effects. Data from both years were pooled prior to analysis.

Though the main effect of cultivar was significant $(P \leq 0.05)$ for all of the fiber parameters measured, this was not unexpected because cultivars are developed and marketed in part based on their unique fiber properties. Mean micronaire ranged from 4.38 (Stoneville BXN 49 B) to 4.98 (Phytogen PSC 355), mean elongation ranged from 5.67 (Fibermax 966) to 8.86\% (Suregrow 747), mean strength ranged from 19.84 (Suregrow 747) to $25.57 \mathrm{~g}$ force per tex (Fibermax 966), mean 50\% span length ranged from 1.41 (Deltapine $555 \mathrm{BR}$ ) to $1.50 \mathrm{~cm}$ (Suregrow 105), and mean 2.5\% span length ranged from 2.80 (Paymaster 1218 BR) to $2.96 \mathrm{~cm}$ (Suregrow 105). However, neither nematicide nor the cultivar $\times$ nematicide interaction were significant for any of the parameters measured, suggesting that neither the nematode nor the chemical applied to suppress the nematode population had any measurable effect on fiber quality. Because only one tolerant cultivar, Paymaster 1218 BR, was included in 
the group subjected to fiber quality measurements, no generalizations about the relationship between tolerance and fiber quality can be made at this time.

\section{Summary}

Suregrow 215 BR, Paymaster 1218 BR, and Deltapine 449 BR may be beneficial to growers in west-central Mississippi because they do not appear to suffer significant yield loss in the presence of reniform nematode. Fiber quality was not affected by reniform nematode, regardless of tolerance level. While tolerance is not an ideal management solution, the use of tolerant cultivars until suitable resistant cultivars are available may reduce economic losses caused by reniform nematode in cotton. Unfortunately, based on our results and other recent reports, it appears that tolerant cotton cultivars are not widely available. It is important for growers to choose cultivars adapted to their region and their farm, keeping in mind that the few with tolerance may not be the best fit for any one farming operation.

\section{Disclaimer}

Mention of trade names or commercial products is solely for the purpose of providing specific information and does not imply recommendation or endorsement by the United States Department of Agriculture.

\section{Acknowledgments}

We are grateful to the following people: D. Boykin, USDA ARS MSA Statistician, for assistance with experimental design and statistical analysis; C. Abel at USDA ARS for use of the Elizabeth, MS, field location; T. Weiss at Dow AgroSciences for Telone II application equipment; G. Burton, P. Fratesi, M. Gafford, O. Houston, K. Jordan, R. Manning, and W. Nokes at USDA ARS and K. Stetina at MSU DREC for technical assistance; and M. Haar and R. Turley for critical review of an earlier version of this manuscript.

\section{Literature Cited}

1. Agrios, G. N. 1997. Plant Pathology, 4th Edn. Academic Press, San Diego, CA.

2. Blasingame, D. 2002. The economics of diseases and nematodes in cotton yield stagnation. (Abstr.) Proc. Beltwide Cott. Conf., Natl. Cotton Counc., Memphis, TN.

3. Blasingame, D., Banks, J. C., Colyer, P. D., Davis, R. M., Gazaway, W. S., Goldburg, N., Kemerait, R. C., Kirkpatrick, T. L., Koenning, S. R., Muller, J., Newman, M. A., Olsen, M., Phipps, P. M., Sciumbato, G. L., Sprenkel, R., Woodward, J. E., Wrather, A., and Patel, M. V. 2008. Cotton disease loss estimate committee report. Proc. Beltwide Cott. Conf. 1:294-297.

4. Blasingame, D., and Patel, M. V. 2004. Cotton disease loss estimate committee report. Proc. Beltwide Cott. Conf. 1:459-460.

5. Blasingame, D., and Patel, M. V. 2005. Cotton disease loss estimate committee report. Proc. Beltwide Cott. Conf. 1:259-262.

6. Blasingame, D., and Patel, M. V. 2006. 2005 cotton disease loss estimate. Proc. Beltwide Cott. Conf. 1:155-157.

7. Byrd, D. W., Jr., Barker, K. R., Ferris, H., Nusbaum, C. J., Griffin, W. E., Small, R. H., and Stone, C. A. 1976. Two semi-automatic elutriators for extracting nematodes and certain fungi from soil. J. Nematol. 8:206-212.

8. Cook, C. G., and Namken, L. N. 1993. Reniform nematode effects on yield and fiber quality of cotton. Proc. Beltwide Cott. Conf. 1:227-228.

9. Cook, C. G., and Namken, L. N. 1994. Influence of reniform nematodes on upland cotton cultivars and breeding lines. Proc. Beltwide Cott. Conf. 1:256-257.

10. Cook, C. G., Robinson, A. F., and Namken, L. N. 1997. Tolerance to Rotylenchulus reniformis and resistance to Meloidogyne incognita race 3 in high-yielding breeding lines of upland cotton. J. Nematol. 29:322-328.

11. Davis, R. F., Koenning, S. R., Kemerait, R. C., Cummings, T. D., and Shurley, W. D. 2003. Rotylenchulus reniformis management in cotton with crop rotation. $J$. Nematol. 35:58-64.

12. Davis, R. F., and May, O. L. 2003. Relationships between tolerance and resistance to Meloidogyne incognita in cotton. J. Nematol. 35:411-416. 
13. Davis, R. F., and Webster, T. M. 2005. Relative host status of selected weeds and crops for Meloidogyne incognita and Rotylenchulus reniformis. J. Cotton Sci. 9:41-46.

14. Jenkins, W. R. 1964. A rapid centrifugal-flotation technique for separating nematodes from soil. Plant Dis. Rep. 48:692.

15. Jones, J. E., Newsom, L. D., and Finley, E. L. 1959. Effect of the reniform nematode on yield, plant characters, and fiber properties of upland cotton. Agron. J. 51:353356.

16. Koenning, S. R., Barker, K. R., and Bowman, D. T. 2000. Tolerance of selected cotton lines to Rotylenchulus reniformis. Suppl. J. Nematol. 32:519-523.

17. Koenning, S. R., and Bowman, D. T. 2005. Cotton tolerance to Hoplolaimus columbus and impact on population densities. Plant Dis. 89:649-653.

18. Koenning, S. R., Kirkpatrick, T. L., Starr, J. L., Wrather, J. A., Walker, N. R., and Mueller, J. D. 2004. Plant-parasitic nematodes attacking cotton in the United States. Plant Dis. 88:100-113.

19. Lawrence, G. W., and McLean, K. S. 2001. Reniform nematodes. Pages 42-44 in: Compendium of Cotton Diseases, 2nd Edn. T. L. Kirkpatrick and C. S. Rothrock, eds. American Phytopathological Society, St. Paul, MN.

20. Patel, M. V. 1999. Cotton nematodes. Coop. Ext. Serv., Field Crops M-132. Mississippi State Univ., Mississippi State, MS.

21. Perkins, H. H., Jr., Ethridge, D. E., and Bragg, C. K. 1984. Fiber. Pages 437-509 in: Cotton. R. J. Kohel and C. F. Lewis, eds. Agron. Monog. No. 24, ASA-CSSA-SSA, Madison, WI.

22. Robinson, A. F. 2007. Reniform in U.S. cotton: When, where, why, and some remedies. Online. Ann. Rev. Phytopathol. 45:11.1-11.25. doi:10.1146/annurev.phyto.45.011107.143949.

23. Sciumbato, G. L., Stetina, S. R., and Young, L. D. 2005. Tolerance of popular cotton varieties to the reniform nematode. (Abstr.) Proc. Beltwide Cott. Conf. 1:150.

24. Stetina, S. R., Sciumbato, G. L., Blessitt, J. A., and Young, L. D. 2006. Cotton cultivars tolerant to reniform nematode. (Abstr.) J. Nematol. 38:294.

25. Stetina, S. R., Young, L. D., Pettigrew, W. T., and Bruns, H. A. 2007. Effect of corncotton rotations on reniform nematode populations and crop yield. Nematropica 37:237-248.

26. Usery, S. R., Jr., Lawrence, K. S., Lawrence, G. W., and Burmester, C. H. 2005. Evaluation of cotton cultivars for resistance and tolerance to Rotylenchulus reniformis. Nematropica 35:121-133.

27. Westphal, A., and Scott, A. W., Jr. 2005. Implementation of soybean in cotton cropping sequences for management of reniform nematode in south Texas. Crop Sci. 45:233-239. 